\title{
EFFECT OF FOAMING AGENT IN SELF CONSOLIDATING LIGHTWEIGHT CONCRETE (SCLC)
}

Article history

Received

16 March 2018

Received in revised form

10 January 2019

Accepted

14 May 2019

Published online

25 June 2019

*Corresponding author ahmad299@salam.uitm.edu.my

Institute for Infrastructure Engineering and Sustainable Management (IIESM), Faculty of Civil Engineering, Universiti Teknologi Mara, 40450 Shah Alam, Selangor, Malaysia

\begin{abstract}
Self-Consolidating Lightweight Concrete (SCLC) is relatively a new concept and can be regarded as a revolutionary development in the field of concrete technology. It is a type of concrete that might not require vibration for placing it and could be produced by reducing the density of concrete. However, the density of normal Self Consolidating Concrete (SCC) is similar to normal concrete approximately $2400 \mathrm{~kg} / \mathrm{m}^{3}$. By using foaming agent, the density of concrete can be reduced up to $1800 \mathrm{~kg} / \mathrm{m}^{3}$. Due to the heavy density of concrete, it will give the initial higher supply cost over conventional concrete, has slowed down its application to general construction. It is also hard to handle for construction and transportation. Therefore, it is advantages to produce SCC with lower density to provide benefit and enhancement of its performance by a combination of two types of concrete technology that is SCC technology and Lightweight Foam Concrete technology. This paper was focused to identify the effect of foaming agent on the fresh properties and compressive strength of SCLC. The influence of foaming agent contained in the range from 0 second, 1 second, 2 second, 3 second and 4 second to the strength characteristic identified in the SCLC. The specimens were tested for compressive strength at $3,7,14$ and 28 days. The result indicated that the compressive strength of SCLC is decreasing when foaming agent content was added. Meanwhile, the flowability of SCLC is increasing when foaming agent content added. Based on the finding, SCLC containing 3 second of foaming agent is achieving the density target, which is $1800 \mathrm{~kg} / \mathrm{m}^{3}$ and better compressive strength performance.
\end{abstract}

Keywords: Self consolidating lightweight concrete, foaming agent, compressive strength, flowability

\begin{abstract}
Abstrak
Konkrit Ringan Padatan Sendiri (SCLC) adalah satu konsep yang baru dan boleh dianggap sebagai pembangunan revolusi dalam bidang teknologi konkrit. la adalah sejenis konkrit yang mungkin tidak memerlukan getaran untuk meletakkannya dan boleh dihasilkan dengan mengurangkan ketumpatan konkrit. Walau bagaimanapun, ketumpatan konkrit padatan sendiri yang biasa (SCC) adalah serupa dengan konkrit biasa iaitu kira-kira $2400 \mathrm{~kg} / \mathrm{m} 3$. Dengan menggunakan agen berbuih, ketumpatan konkrit boleh dikurangkan sehingga $1800 \mathrm{~kg} / \mathrm{m} 3$. Oleh kerana kepadatan konkrit berat, ia akan memberi kos pembekalan yang lebih tinggi awal berbanding konkrit konvensional dan telah melambatkan penggunaannya kepada pembinaan umum. la juga sukar dikendalikan untuk pembinaan dan pengangkutan. Oleh itu, ia memberi kelebihan untuk menghasilkan SCC dengan ketumpatan yang lebih rendah untuk memberikan faedah dan peningkatan prestasi dengan gabungan dua jenis teknologi konkrit iaitu teknologi SCC dan teknologi konkrit buih ringan. Kajian ini memfokuskan untuk mengenal pasti kesan agen berbuih pada sifat-sifat konkrit basah dan kekuatan mampatan bagi SCLC. Pengaruh agen berbuih yang terkandung dalam julat dari 0 saat, 1 saat, 2 saat, 3 saat dan 4 saat kepada ciri kekuatan yang dikenalpasti dalam SCLC. Spesimen telah diuji untuk kekuatan mampatan pada 3, 7, 14 dan 28 hari. Hasilnya menunjukkan bahawa kekuatan mampatan SCLC menurun apabila kandungan agen berbuih telah ditambah. Sementara itu, keboleh aliran SCLC semakin meningkat apabila kandungan agen berbuih ditambahkan. Berdasarkan penemuannya, SCLC yang mengandungi 3 saat agen berbuih mencapai sasaran kepadatan, iaitu $1800 \mathrm{~kg} / \mathrm{m} 3$ dan prestasi kekuatan mampatan yang lebih baik.
\end{abstract}

Kata kunci: Konkrit ringan padatan sendiri, agent buih, kekuatan mampatan, keboleh aliran 


\subsection{INTRODUCTION}

Self-consolidating concrete (SCC), also known as selfcompacting concrete, is a concrete that compacts under its own weight without the need of mechanical vibration, and it has an adequate cohesion for it to be handled without segregation or bleeding [1-2]. It is able to flow under its own weight and can completely fill the framework even with congested reinforcement. The hardened-concrete is dense, homogenous and has the same engineering properties and durability as traditional vibrated concrete [3]. Consequently, SCC can be used when there is a need to do concrete works in constricted and hard to reach that particular area. To have these characteristics, SCC uses a low waterpowder ratio, with the addition of high range water reducing admixtures, where superplasticizer is usually used in its mix design. Since, cement particles tend to clump together when they are mixed with water, therefore superplasticizer temporarily halt this process, making the concrete flowable for a longer period of time.

Although concrete is stronger and more durable [3334], it also has high dead load for the structural component of RC building or decorative frame, plaster ceiling and others. Therefore, the development of lightweight concrete acts as an excellent solution in decreasing the dead load of the structure [4].

Consequently, in recent years, the construction industry has shown significant interest in the use of lightweight concrete as a building material in construction applications. Indeed, in the construction industry, self-weight of concrete represents a very large proportion of the total load on the structure, hence this is clearly beneficial in reducing the density of concrete. The typical range of densities of lightweight concrete is approximately $300 \mathrm{~kg} / \mathrm{m}^{3}$ to $1850 \mathrm{~kg} / \mathrm{m}^{3}$ [5], which is lighter than normal weight concrete, which is within the range of $2200-2600 \mathrm{~kg} / \mathrm{m}^{3}$ [6]. Lightweight concrete has been successfully utilized since the ancient Roman times and it has gained its popularity due to its low density, superior thermal insulation, reduction of dead load, faster building rate and lower haulage cost [7-8].

Many types of lightweight concrete help to reduce the concrete density. Thus, the lightweight concrete is created by introducing large air voids in the cement paste, which is formed as foamed concrete [5]. As for Foam Concrete (FC), it is a concrete that is designed to acquire density within the range of $300 \mathrm{~kg} / \mathrm{m}^{3}$ to 1800 $\mathrm{kg} / \mathrm{m}^{3}$ (at least $25 \%$ density reduction), and besides that, its strength depends on the density of the concrete, where the lower the density of the concrete, the lower its strength [9]. As it is one of lightweight concrete, to attain a density lower than normal conventional concrete, foam concrete is formed through the removal of coarse aggregates and the addition of foam, which is made from foaming agent, in its mix design.

Therefore, this paper presents the investigation of SCLC in fresh and hardened states containing foaming agent. The main objective of this research was to assess the effects of foaming agent on the workability and compressive strength of SCLC.

\subsection{METHODOLOGY}

\subsection{Materials Selection}

Materials used in this research were chosen according to the specification that meets the requirement of appropriate British Standards.

The cement used in this research was Ordinary Portland Cement (OPC), which was used as a binder in all concrete mixes. The OPC was identified to fulfill the standard specifications of BS EN 197-1:2000 [10]. The physical properties and chemical composition of cement used in the present research are shown in Table 1 and Table 2 respectively. Table 2 refers to $X$-ray Fluorescence Spectrophotometer (XRF) test result.

Table 1 Physical properties of OPC used in the present research [11]

\begin{tabular}{llc}
\hline No. & & Physical Properties \\
\hline 1 & Relative Density & 2.25 \\
2 & Surface Area & $13000 \mathrm{~cm}^{2} / \mathrm{g}$ \\
3 & Ph & $11-12$ \\
4 & Colour & Gray \\
5 & Particle Size, D90 & $11 \mu \mathrm{m}$ \\
\hline
\end{tabular}

Tap water was used for concrete mixture, as it contains no substance and free from impurities that could affect the concrete and can have an appreciable harmful effect upon the strength of concrete. Specifications for water test on water for mixing concrete conform to BS EN 1008:2002 [15].

The type of superplasticizer used in this experiment research is MASTER GLENIUM 8589, also known as Poly Carboxylic Ether (PCE). For all batched, $1.0 \mathrm{~L}$ (of $100 \mathrm{~kg}$ of cement content) of superplasticizer was added to the concrete mixture.

Table 2 Chemical composition of OPC used in the present research (X-ray Florescent Test) [12]

\begin{tabular}{lll}
\hline No. & Oxide & Percentage \\
\hline 1 & $\mathrm{SiO}_{2}$ & 15.05 \\
2 & $\mathrm{CaO}$ & 72.17 \\
3 & $\mathrm{Al}_{2} \mathrm{O}_{3}$ & 2.56 \\
4 & $\mathrm{Fe}_{2} \mathrm{O}_{3}$ & 4.00 \\
5 & $\mathrm{MgO}$ & 1.27 \\
6 & $\mathrm{MnO}$ & 0.06 \\
7 & $\mathrm{Na}_{2} \mathrm{O}$ & 0.08 \\
8 & $\mathrm{~K}_{2} \mathrm{O}$ & 0.41 \\
9 & $\mathrm{SO}_{3}$ & 2.90 \\
10 & $\mathrm{P}_{2} \mathrm{O}_{5}$ & 0.06 \\
11 & $\mathrm{TiO}_{2}$ & 0.12 \\
12 & $\mathrm{LO}$ & 1.33 \\
\hline
\end{tabular}

Coarse aggregate used in this research is crushed mining type and the natural river sand was selected as fine aggregate. The maximum size of coarse aggregates and fine aggregate is $10 \mathrm{~mm}$ and $5 \mathrm{~mm}$ used in this research respectively. The size of the 
aggregate selected was compliance to the specification described in BS EN 933-1:2012 [13]. The coarse aggregate content in SCLC is kept either equal to or less than that of the fine aggregate content [14].

The foaming agent to be utilized in this research is synthetic-based, namely Meyco SLF 30 supplied by CT Technology Enterprise and it is packed in a $20 \mathrm{~L}$ container. The foam was formulated to produce air bubbles that are able to resist the physical and chemical forces imposed on them during mixing, placing and hardening of concrete.

\subsection{Experimental Method}

This research was carried out to identify the effect of foaming agent on the fresh properties and compressive strength of SCLC. The SCLC properties covered in this research include properties in the fresh and hardened state of the SCLC. For this research, the dimension size of the specimen was $100 \mathrm{~mm} \times 100 \mathrm{~mm} \times 100 \mathrm{~mm}$. The effect of adding a foaming agent on compressive strength of SCLC was determined at the age 3, 7, 14 and 28 days.

\subsection{Design of Mix Proportion}

The basic components of mix composition of SCLC are the same as used in conventional concrete. The concrete mix for this research was designed in two stages.

In the first stage, the SCLC mix was designed based on the British method Department of Environment revised in 1988 [16]. This determined the quantity by weight of the cement content, free water and total aggregates (Fine aggregate and Coarse Aggregate).

Table 3 Mix Proportion of SCLC

\begin{tabular}{|c|c|c|c|c|c|c|c|c|}
\hline \multirow[t]{2}{*}{ Mix Code } & \multirow{2}{*}{$\begin{array}{c}\text { Cement } \\
\mathrm{kg} / \mathrm{m}^{3} \\
\end{array}$} & \multirow{2}{*}{$\begin{array}{l}\text { Water } \\
\mathrm{kg} / \mathrm{m}^{3} \\
\end{array}$} & \multirow{2}{*}{$\begin{array}{c}\text { Fine } \\
\text { Aggregate } \\
\mathrm{kg} / \mathrm{m}^{3} \\
\end{array}$} & \multirow{2}{*}{$\begin{array}{c}\text { Coarse } \\
\text { Aggregate } \\
\mathrm{kg} / \mathrm{m}^{3} \\
\end{array}$} & \multicolumn{2}{|c|}{ Foaming Agent } & \multicolumn{2}{|c|}{ Superplasticizer } \\
\hline & & & & & $\mathrm{Sec}$ & $\mathrm{L} / \mathrm{m}^{3}$ & $\mathrm{~L} / 100 \mathrm{~kg}$ & $\mathrm{~L} / \mathrm{m}^{3}$ \\
\hline Ml & 338 & 181 & 769 & 512 & 0 & 0 & 1.0 & 3.38 \\
\hline M2 & 338 & 181 & 769 & 512 & 1 & 231 & 1.0 & 3.38 \\
\hline M3 & 338 & 181 & 769 & 512 & 2 & 231 & 1.0 & 3.38 \\
\hline M4 & 338 & 181 & 769 & 512 & 3 & 231 & 1.0 & 3.38 \\
\hline M5 & 338 & 181 & 769 & 512 & 4 & 231 & 1.0 & 3.38 \\
\hline
\end{tabular}

In the second stage, the mix design of SCLC was to determine the amount of foaming agent. This mix design was used the in-house developed spreadsheet which is leading to a new modified mix proportioning for SCLC. Table 3 shows the mix proportion of SCLC containing foaming agent.

\subsection{Casting and Curing}

To ensure the process of batching is done effectively to give the concrete better strength; the mixing process was done in a concrete pan mixer machine. The material used in the concrete mixtures was measured to its specific weight as calculated in the design mix. The concrete mixer cleaned by wiping it with a wet cloth. Fine and coarse aggregates were added in the mixer for thorough mixing. The cement was gradually added to the mixture and mixed for 1 minute. The water was gradually added, followed by superplasticiser. Finally, the foam was added into the mixture. The size of the moulds used are $100 \mathrm{~mm} \times 100 \mathrm{~mm} \times 100 \mathrm{~mm}$.

After the process of casting, the SCLC specimens were cured in water. The process of curing in water was conducted under the laboratory condition for 28 days. The concrete cube specimens were water cured in curing tank until the day of testing at 3, 7, 14 and 28 days. The process of curing is carried out in accordance with BS EN 12390-2:2009 [17].

\subsection{Test Procedures}

Three (3) type of test procedures was carried out which are properties of aggregate and foaming agent, fresh concrete and hardened concrete.

There are many types of testing for properties of aggregate. Sieve analysis method is according to BS EN 933-1:2012 [13]. The aggregate crushing value test is conducted to determine the ability of an aggregate to resist crushing which was according to BS 812-110:1990 [18]. The procedure of aggregate impact value is according to BS 812-112:1990 [19]. The standard procedure of water absorption is prescribed in BS EN 1097-6:2013 [20]. In conducting the specific gravity procedure followed is BS EN 1097-6:2013 [20] on saturated surface dry basis. Elongation and the flakiness index test were accorded to BS 812-105.2:1990 [21] and BS EN 933-3:2012 [22] respectively.

The properties of foaming agent were determined based on chemical and physical testing. The chemical property of foaming agent was determined using Fourier Transform Infra-Red spectroscopy (FTIR). Meanwhile, the physical properties were used Viscosity Measurement and Stability Testing.

The fresh concrete tests conducted for this research were slump flow test for measuring flowability. The slump flow test is used to assess the horizontal free flow of SCLC in the absence of obstructions. The test method is based on the conventional slump test as in accordance with British Standard BS EN 206-9:2010 [23]. 
After curing, the specimens of SCLC were tested for compression test. The compressive strength test was tested as accordance to BS EN 12390- 3: 2009 [24].

\subsection{RESULT AND DISCUSSION}

\subsection{Physical Properties of Aggregates}

Particle size distribution is to grade the aggregate, which is important, and play a major rule in the design mix of concrete. Table 4 presents the results obtained from laboratory test conducted on physical properties of all the aggregates in terms of water absorption, aggregate impact value, aggregate crushing value, specific gravity, elongation index, bulk density and flakiness index in accordance to British Standards.

Table 4 Physical properties of aggregate

\begin{tabular}{lll}
\hline No. & Laboratory Test Conducted & Natural Aggregate \\
\hline 1 & Grading / Sieve Analysis & Graded Aggregate \\
2 & Texture & Smooth \\
3 & Bulk Specific Gravity $\quad-$ & 2.66 \\
& Saturated Surface Dry (SSD) & \\
4 & Apparent Specific Gravity & 2.67 \\
5 & Specific Gravity & 2.65 \\
6 & Water Absorption \% & 0.54 \\
7 & Aggregate Crushing Value \% & 21.09 \\
8 & Elongation \% & 2.1 \\
9 & Flakiness \% & 49.33 \\
10 & Aggregate Impact Value \% & 27.23 \\
11 & Moisture Content \% & 0.35 \\
\hline
\end{tabular}

From the result, specific gravity of natural aggregate under saturated surface dry, apparent and normal are $2.67,2.66$, and 2.65 respectively. Water absorption of NA is $0.54 \%$. This is complying with BS EN 12620:2002+A1:2008 [25], which states that the $10 \%$ maximum value of water absorption of coarse aggregate. Aggregate with water absorption this value can use for the application in structural element, non-structural element and insulation barrier. The aggregate crushing value for NA is $21.09 \%$. According to BS EN 12620: 2002 + A: 2008 [25], aggregate with crushing value less than $25 \%$, it can be used in heavy duty floor, crushing value of more than $30 \%$, is more suitable to be used in concrete for wearing surfaces and for more than $45 \%$, it can be used for other concrete purposes.

According to Claudio et al. (2014) [26] stated that aggregate granite an irregular shape, rough texture, and low absorption. The flakiness and elongation of aggregate are $19 \%$ and $27 \%$, respectively, which is attributable to differences in the particle shape of each natural aggregate.

\subsection{Properties of Foaming Agent}

There are two (2) types of properties of foaming agent, which are chemical properties and physical properties. The testing for chemical property is FTIR.
Fourier Transform Infra-Red spectroscopy FTIR is an instrument for analysis the functional group contain in the samples [27]. The observation done by FTIR was based on the wavelength value $\mathrm{cm}^{-1}$ and elucidation process based on the standard correlation chart [28-29]. Figure 1 and Table 5 show the FTIR spectrum of synthetic foaming agent and the functional groups detect respectively.

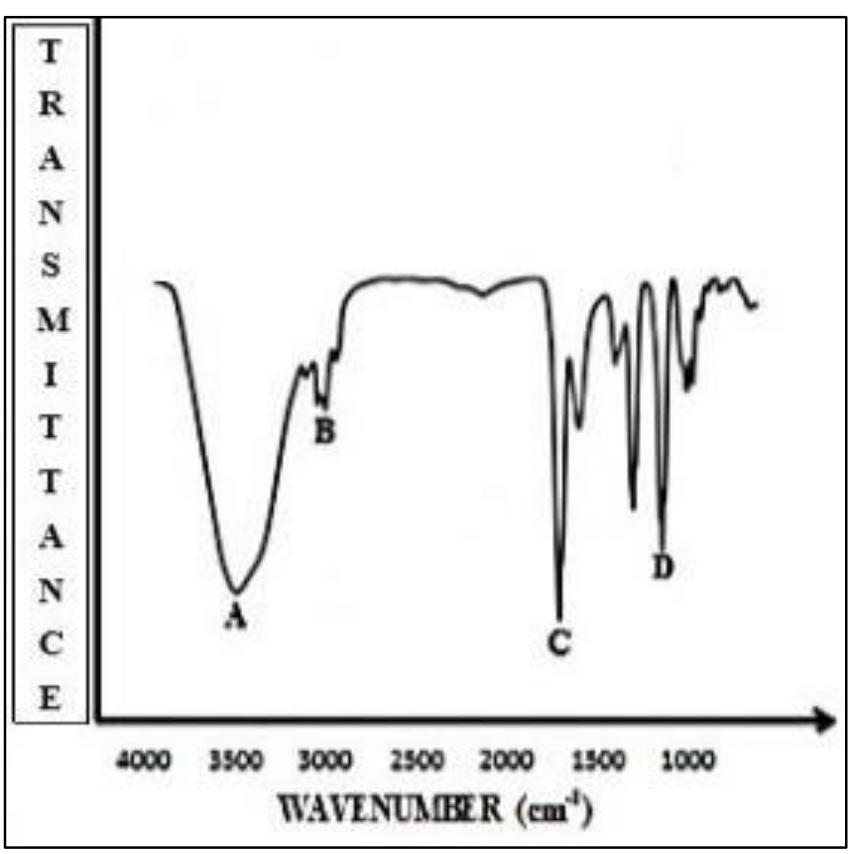

Figure 1 FTIR spectrum of synthetic foaming agent

Table 5 FTIR spectrum of synthetic foaming agent and the functional groups detected

\begin{tabular}{lll}
\hline Label & Peak Observed & Frequency, $\mathbf{c m}^{-1}$ \\
\hline A & N-H stretch & $3250-3200$ \\
\hline B & C-H, Lipids & $3050-3000$ \\
\hline C & C=O, Lipids (esters) & $1745-1720$ \\
\hline D & Amide III, Proteins & $1330-1200$ \\
\hline
\end{tabular}

The synthetic foaming agent has been analyzed and the spectrum detected at frequency $3250-3200$ was $\mathrm{N}$ $\mathrm{H}$ stretching. However, other spectrum, such $\mathrm{C}=\mathrm{O}$, lipids was observed at frequency 1720-1745 for synthetic foaming agent. The synthetic foaming agent spectrum showed the Amide III Proteins group at lower frequency 1330-1200. The synthetic foaming agent spectrum was found $\mathrm{C}-\mathrm{H}$ compounds spectrum at 3050-3000 frequency with stretching formation. Finally yet importantly, the spectrum that formed at lowest frequency $1170-1070$ is -CO-O-C, Carboxylic group. This compound absorbed lowest energy and bending formation was identified.

The physical characterization is an important factor to determine the flowability of the foaming agent solution. As to measure, the value of viscosity of this experimental sample has been analyzed by using 
Viscometer. The Viscometer that has been used for this experiment is by Bookfield Viscometer DV-I- Prime. This is the basic method in order to measure the viscosity value. Table 6 shows the viscosity measurement of synthetic foaming agent used in this research.

Table 6 Viscosity measurement of synthetic foaming agent

\begin{tabular}{|c|c|c|c|c|c|c|}
\hline \multirow{2}{*}{$\begin{array}{l}\text { Type of } \\
\text { sample }\end{array}$} & \multirow{2}{*}{$\begin{array}{l}\text { Speed, } \\
\text { rpm }\end{array}$} & \multicolumn{4}{|c|}{ Time, minute } & \multirow{2}{*}{$\begin{array}{c}\text { Total } \\
\text { Viscosity } \\
\text { CP }\end{array}$} \\
\hline & & 0 & 1 & 2 & 3 & \\
\hline \multirow{4}{*}{$\begin{array}{c}\text { Synthetic } \\
\text { Foaming } \\
\text { Agent }\end{array}$} & 10 & 0 & 140 & 140 & 140 & 140 \\
\hline & 20 & 0 & 77.5 & 62.5 & 82.5 & 74.17 \\
\hline & 50 & 0 & 21 & 22 & 23 & 22 \\
\hline & 100 & 0 & 14.5 & 14.5 & 14.5 & 14.5 \\
\hline
\end{tabular}

From Table 6, the viscosity value, $\mathrm{CP}$ is 14.5. The physical characteristic of synthetic foaming agent, which directly observed it is very light and contains a lot of water. Moreover, this sample is commercially formulated from manufactured and may be diluted for commercial purposes. During the analysis, the speed in rpm should be controlled to ensure no large bubble is formed. This is due the indirect air introduced into the foaming agent sample especially for synthetic foaming agent, which easy to produce bubbles. When the bubble produced, the reading of total viscosity value, CP will change. This analysis study was tested that the sample which has greater viscosity. This value of viscosity is essential to define properties of the foam. Then it has high potential to contribute to a stable and firm of foam.

Stability test of foaming agent has been tested for its foam's ability by using the cylindrical measurement method. This test is one of the physical properties of foaming agent. From the analysis, the effect was considered based on volume foam expansions, $\mathrm{mL}$ and time taken, minute $(\mathrm{m})$. Sample preparation for synthetic foaming agent was required pressurized pump in order to produce foam. The time taken was started in early 0 until 135 minutes, which at this final time no foaming occurs. Figure 2 shows the stability measurement graph of synthetic foaming agent.

From the result, the analysis has attributed to the prediction of foam stability. This data were provided significant result to determine the concrete properties both for fresh and hardened concrete. Previous study by Louvet et al. (2009) [30] and Lehrsch et al. (2012) [31] had mentioned that the drainage effect will be reduced the foam stability and increased the foam ruptured.

Other factors to be stated are when the action of bursting of liquid films and as a result the neighbouring bubbles will be separated. There are three main factors were contributed to the ripening and coarsening of the foam bubbles. The most common are liquid drainage which driven by gravity, pressure and coalescence. If one these contributors factor happens, can cause the liquid in the Plateau Border (PB) will be drained out from the lamella. As a result, the increasing of foam film thickness and the bubble shape ruptured. This phenomenon can promote to less stable foam will be considered to have less stable foam. Naturally gravity was the biggest barrier to overcome in order to provide the stable foam.

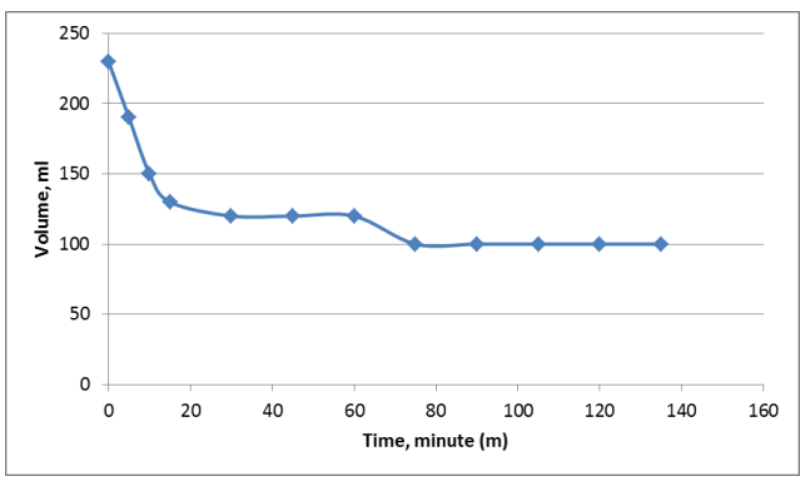

Figure 2 Stability measurement graph of synthetic foaming agent

Another factor also can be considered for foam stability, such as foaming agent concentration, particles size and nature of surfactants. The stability of the foam is possible to be achieved by to control all contributors that influence the foam stability. Moreover, the foam is thermally unstable because it tends to self-destruct due to the liquid drainage and bubble coalescence. The viscosity of the liquid is an important to get stable foam. Very viscous liquid has the potential to produce very stable and low drainage effect. Amount of water to be added must be verified in order to avoid the severe drainage in plateau border, PB [32].

\subsection{Fresh Properties of SCLC}

Fresh concrete produced in this research were tested for flowability ability to satisfy the requirement for selfconsolidating concrete before the concrete specimens were cast into $100 \mathrm{~mm} \times 100 \mathrm{~mm} \times 100 \mathrm{~mm}$ cubes. The flowability ability of normal SCC and SCLC containing foaming agent at specified 1 second, 2 seconds, 3 seconds and 4 seconds are stated in Table 7.

The slump flow value describes the flowability of a fresh mix in unconfined conditions. In this research, the slump flow diameter of all specimens tested lies between $550 \mathrm{~mm}$ and $850 \mathrm{~mm}$ [14].

Table 7 Flowability of SCLC

\begin{tabular}{|c|c|c|c|}
\hline \multirow{2}{*}{$\begin{array}{l}\text { Mix } \\
\text { Code }\end{array}$} & \multirow{2}{*}{$\begin{array}{l}\begin{array}{l}\text { Foaming } \\
\text { Agent }\end{array} \\
\text { Second }\end{array}$} & \multicolumn{2}{|c|}{ Slump flow diameter (mm) } \\
\hline & & $\begin{array}{l}\text { Before adding } \\
\text { Foam }\end{array}$ & $\begin{array}{l}\text { After } \\
\text { Foam }\end{array}$ \\
\hline$M 1$ & 0 & \multirow{5}{*}{570} & - \\
\hline M2 & 1 & & 635 \\
\hline M3 & 2 & & 670 \\
\hline M4 & 3 & & 700 \\
\hline M5 & 4 & & 750 \\
\hline
\end{tabular}


In this case, the requirement for self-consolidating concrete as per the EFNARC (2005) [14] which specified the following typical slump-flow classes for a range of applications:

i) SFl (550-650 $\mathrm{mm}$ ) is appropriate for unreinforced or slightly reinforced concrete structures that are cast from top with free displacement from delivery point (e.g. Housing slabs), casting by a pump injection system (e.g. Tunnel linings) and sections that are small enough to prevent long horizontal flow (e.g. Piles and some deep foundations).

ii) SF2 (660-750 $\mathrm{mm})$ is suitable for many normal applications (e.g. Walls and column).

iii) SF3 (760- $850 \mathrm{~mm})$ is typically produced with small maximum size aggregates (less than $16 \mathrm{~mm}$ ) for very congested structures.

Therefore, all the concrete specimens produced in this research satisfied the slump flow for SCLC classes SF1 and SF2 as mentioned above. The results indicated that slightly increasing by the time of flow of foaming agent contained in the fresh resulted detrimental effect on the flowability of the fresh SCLC.

\subsection{Density and Compressive Strength of SCLC}

The density and the compressive strength of SCLC for day $3,7,14$ and 28 after curing for all batches is as shown in Figure 3 and Figure 4 respectively.

Based on Figure 3, it shows that the control sample (M1) has a density of about $2385 \mathrm{~kg} / \mathrm{m}^{3}$. By adding 1, 2, 3 and 4 second of foam into the mix, the density of the concrete decreased to 2243, 2071, 1824 and $1679 \mathrm{~kg} / \mathrm{m}^{3}$ respectively. Therefore, it can be concluded that the addition of foam reduced the density of SCLC.

The control sample $(\mathrm{M} 1)$, has a compressive strength of $22.41 \mathrm{~N} / \mathrm{mm}^{2}$ at 3 days, increased to $30.39,35.25$ and $39.45 \mathrm{~N} / \mathrm{mm}^{2}$ on 7 days, 14 days and 28 days respectively. By adding 1 second of foam flow, the compressive strength at 3 days reduced to 20.35 $\mathrm{N} / \mathrm{mm} 2$, followed by $26.84,31.52$ and $34.21 \mathrm{~N} / \mathrm{mm}^{2}$ on 7 day, 14 day and 28 day respectively. The addition of 2 second of foam flow into the mix, the compressive strength is $15.36,24.86,28.45$ and $30.12 \mathrm{~N} / \mathrm{mm}^{2}$ for 3 day, 7 day, 14 day and 28 day respectively. The same could be said for the addition of 3 second of foam flow, where for 3 day, 7 day, 14 day and 28 day, the compressive strength of SCLC is 12.09, 19.90, 23.50 and $24.82 \mathrm{~N} / \mathrm{mm} 2$ respectively. As for the addition of 4 second of foam flow, the compressive strength is $6.82,11.36$, and 14.64 $\mathrm{N} / \mathrm{mm} 2$ for 3 day, 7 day, 14 day and 28 day respectively.

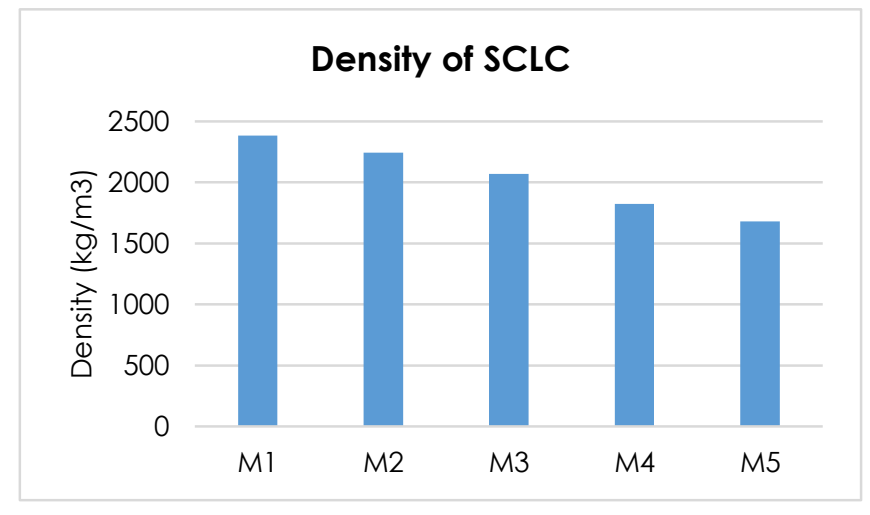

Figure 3 Density of SCLC

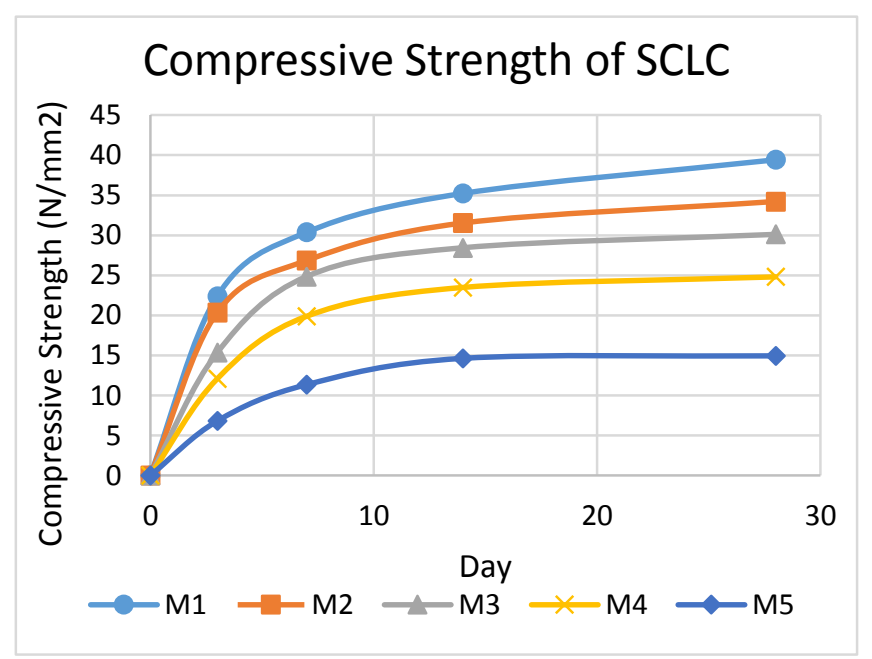

Figure 4 Compressive Strength Development of SCLC

It can be seen that the more foaming agent added to the concrete, the lesser its compressive strength. This is due to the voids formed present in the concrete. It is shown that the compressive strength of concrete deteriorated as more foam is added into the mix, due to the decreasing of the concrete density. As the density of the SCLFC reaches about $1800 \mathrm{~kg} / \mathrm{m}^{3}$, the compressive strength of the concrete deteriorated about $75 \%$ of the compressive strength of normal SCC. Therefore, SCLFC cannot be used as a load bearing structure. 


\subsection{CONCLUSION}

Based on the objectives of this research, it can be concluded that the specific gravity and water absorption of natural aggregate is 2.65 and 0.54 respectively. The chemical analysis by using FTIR, foaming agent that used has $\mathrm{N}-\mathrm{H}$ stretch, $\mathrm{C}-\mathrm{H}$ Lipids, $\mathrm{C}=\mathrm{O}$ Lipids (esters) and Amide III, proteins. Meanwhile, the viscosity value for foaming agent is $14.5 \mathrm{cP}$. The flowability of SCLC increases when additional foam added into the mix. The slump flow of this research is in the range $570 \mathrm{~mm}-750 \mathrm{~mm}$. The compressive strength of SCLC decreases as the density decreases due to the addition of foam into the mix.

\section{Acknowledgement}

The author would like to acknowledge the Research Management Institute for providing the "Geran Inisiatif Penyeliaan" (GIP) (600-IRMI/GIP 5/3 (0004/2016)), Institute for Infrastructure Engineering and Sustainable Management (IIESM) and Faculty of Civil Engineering, Universiti Teknologi MARA for providing the facilities to accomplish the experimental work for this research.

\section{References}

[1] Gang, T. and Chandramohan, N. 2016. Experimental Study on Replacement of Bagasse Ash as Cement and Quarry Dust as Sand in Self-Compacting Concrete. Journal of Mechanical and Civil Engineering. 2(6): 15-24.

[2] Panda, K. C. and Bal, P. K. 2013. Properties Of Self Compacting Concrete Using Recycled Coarse Aggregate, Chemical, Civil and Mechanical Engineering Tracks of 3rd Nirma University International Conference on Engineering (NUiCONE2012). Procedia Engineering. 51: 159-164.

[3] Abdulkader Ismail Al-Hadithi and Nahla Naji Hilal. 2016. The Possibility of Enhancing Some Properties of Self-compacting Concrete by Adding Waste Plastic Fibers. Journal of Building Engineering. 8: 20-28.

[4] Behnam, V. and Shami, N. 2016. Mix Design of Light-weight Self-compacting Concrete. Case Studies in Construction Materials. 4: 1-14.

[5] Neville, A. M. 2002. Properties of Concrete. London, Pearson Education Limited.

[6] Aguilar, R. A., Diaz, O. B. and Garcia, J. I. E. 2010. Lightweight Concretes of Activated Metakaolin-Fly ash Binders, with Blast Furnace Slag Aggregate. Construction and Building Materials. 1166-1175.

[7] Bai, Y., Ibrahim, R., and Basheer, P. A. M. 2004. Properties of Lightweight Concrete Manufactured with Fly Ash, Furnace Bottom Ash, and Lytag. Proceedings of the International Workshop on Sustainable Development and Concrete Technology Beijing, China.

[8] Wongkeo, W., and Chaipanich, A. 2010. Compressive Strength, Microstructure and Thermal Analysis of Autoclave and Air Cured Structural Lightweight Concrete made with Coal Bottom Ash and Silica Fume. Materials Science and Engineering. 527: 3676-3684.

[9] Mohd Zairul, A., Ahmad Mujahid, A., \& Ismail, A. 2010. Behavior of Foamed Concrete under Quasi State Indentation. International Journal of Sustainable Construction Engineering \& Technology. 1(1): 57-72.

[10] BS EN 197-1:2000. Cement - Part 1: Composition, Specifications and Conformity Criteria for Common Cements. British Standard. 1-47.
[11] Mohd Ridzuan, A. R., Mohd Fauzi, M. A., Arshad, M. F., Harun M. S., and Jasmi, N. 2018. Effect of Limestone Powder in Self Consolidating Lightweight Foam Concrete. Journal of Solid State Phenomena. 280: 469-475.

[12] Ridzuan, A. R. M, Fauzi, M. A. M., Kassim, A. 2011. The Evaluation of Self Consolidating Concrete Incorporating Crushed Concrete Waste Aggregate. Proceeding of 3rd International Symposium \& Exhibition in Sustainable Energy \& Environment. 100-105.

[13] BS EN 933-1:2012. Tests for Geometrical Properties of Aggregates. Determination of Particle Size Distribution. Sieving Method, British Standard. 1-22.

[14] EFNARC. 2005. The European Guidelines for Self-Compacting Concrete Specification, Production and Use, May 2005. 1-68.

[15] BS EN 1008:2002. Mixing Water for Concrete. Specification for Sampling, Testing and Assessing the Suitability of Water, Including Water Recovered from Processes in the Concrete Industry, as Mixing Water for Concrete. British Standard. 1-22.

[16] Aginam, C. H., Umenwaliri, S. N. and Nwakire, C. 2013. Influence of Mix Design Methods on the Compressive Strength of Concrete. Progress in Energy Combustion Science ARPN Journal of Engineering and Applied Sciences. 8(6): 438-444.

[17] BS EN 12390-2:2009. Testing Hardened Concrete. Making and Curing Specimens for Strength Tests, British Standard. 1-12.

[18] BS 812-110:1990. Testing Aggregates. Methods for Determination of Aggregate Crushing Value (ACV), British Standard. 1-12.

[19] BS 812-112:1990. Testing Aggregates. Method for Determination of Aggregate Impact Value (AIV), British Standard. 1-14.

[20] BS EN 1097-6:2013. Tests for Mechanical and Physical Properties of Aggregates. Determination of Particle Density and Water Absorption, British Standard. 1-54.

[21] BS 812-105.2:1990. Testing Aggregates. Methods for Determination of Particle Shape. Elongation Index of Coarse Aggregate, British Standard. 1-12.

[22] BS EN 933-3:2012. Tests for Geometrical Properties of Aggregates. Determination of Particle Shape. Flakiness Index, British Standard. 1-16.

[23] BS EN 206-9: 2010. Concrete. Additional Rules for Self Compacting Concrete (SCC), British Standard. 1-16.

[24] BS EN 12390-3: 2009. Testing Hardened Concrete. Compressive Strength of Test Specimens, British Standard. 122.

[25] BS EN 12620:2002+A1:2008. Aggregates for Concrete, British Standard. 1-60.

[26] Claudio, J. Z., Ángel, A. D. M., and R. L. Z. 2014. Influence of Natural Coarse Aggregate Type on the Transport Properties of Recycled Concrete. Journal of Materials in Civil Engineering. 26(6): 04014006-1-14006-9.

[27] Drenckhan, W., Hutzler, S., \& Weaire, D. 2005. Foam Physics: the Simplest Example of Soft Condensed Matter. AIP Conference Proceedings. 748: 22-28.

[28] Pitois, O., Fritz, C., \& Vignes-Adler, M. 2005. Liquid Drainage through Aqueous Foam: Study of the Flow on the Bubble Scale. Journal of Colloid and Interface Science. 282(2): 45865.

[29] Hafiz, M. M. A., Ridzuan, A. R. M., Fadzil, M. A. and Nurliza, J. 2013. Chemical Characterization of Used Cooking Oil Foaming Agent as Admixture in Foamed Concrete. International of Civil and Infrastructure Engineering Conference (InCiEC 2013). 191-200.

[30] Louvet, N., Rouyer, F., \& Pitois, O. 2009. Ripening of a Draining Foam Bubble. Journal of Colloid and Interface Science. 334(1): 82-86.

[31] Lehrsch, G. A., Sojka, R. E., \& Koehn, A. C. 2012. Surfactant Effects on Soil Aggregate Tensile Strength. Geoderma Journal. 189-190: 199-206.

[32] Shrestha, L. K., Shrestha, R. G., Sharma, S. C., \& Aramaki, K. 2008. Stabilization of Nonaqueous Foam with Lamellar Liquid Crystal Particles in Diglycerol Monolaurate/Olive Oil System. Journal of Colloid and Interface Science. 328(1): 172-179. 